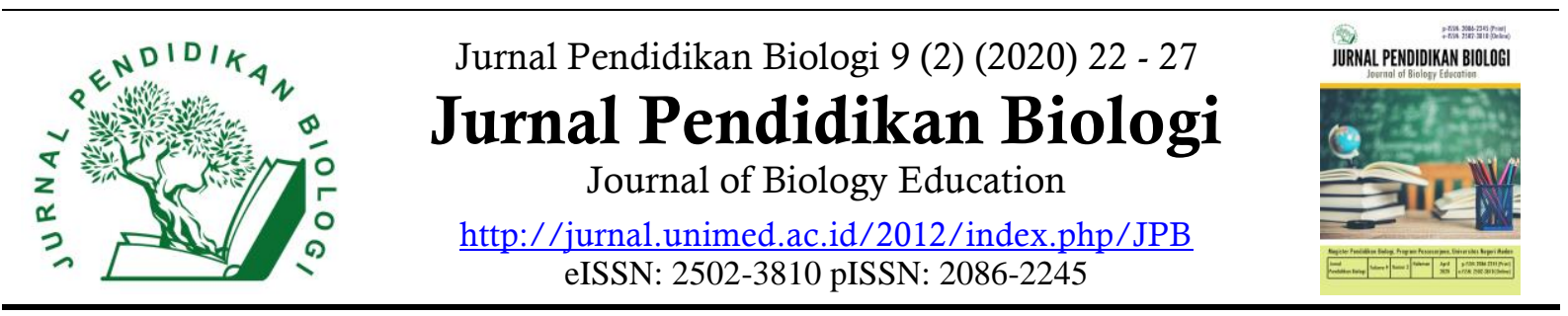

\title{
Pengaruh Model Pembelajaran Kooperatif Tipe Make A Match Terhadap Hasil Belajar Siswa
}

\author{
Yusni Welinda Mbau ${ }^{1}$, Agus Maramba Meha ${ }^{1^{*}}$, Yonatan Foeh $^{2}$ \\ ${ }^{1}$ Program Studi Pendidikan Biologi, Fakultas Keguruan dan Ilmu Pendidikan, Universitas Kristen Artha Wacana \\ Kupang, Jl. Adicipto Oesapa, 85228, Nusa Tenggara Timur, Indonesia \\ ${ }^{2}$ Institut Agama Kristen Negeri Kupang, Jl. Cak Doko, Kupang, Nusa Tenggara Timur, Indonesia
}

\section{INFO ARTIKEL}

\section{Histori Artikel}

Received 8 Juli 2020

Revised 2 Oktober 2020

Accepted 25 Oktober 2020

Published 8 November 2020

\section{Keywords:}

Make a match,

Student learning outcomes,

Cooperative learning

\begin{abstract}
The problem in this study is the low learning outcomes of class VII students of SMP Negeri 20 Kupang. This study aims to determine the effect of the Make A Match type of cooperative learning model on learning outcomes. The experimental research method used is the Posttest-Only Control Group Design. The population of class VII students was 253 students and the sample of class VIID and class VIIH was 54 students. Data collection using learning outcomes tests. Analyzed using t-test, assisted by SPSS For Windows version 23. Hypothesis test results obtained $t_{\text {count }} 8,194>2,00665 t_{\text {table }}$ at 0,000 significance or less than 0.05 , indicating that there are differences in student learning outcomes between the control and experimental classes. It is shown by increasing students' understanding of the digestive system material, students look very enthusiastic in learning, have curiosity, and dare to express opinions during the learning process. Therefore, the Make A Match learning model has great potential in developing students' ideas on problem-solving in learning, as evidenced by the high percentage of student learning outcomes, namely C1 $93.055 \%$, C2 $75.462 \%$, and C3 73.765\%.
\end{abstract}

Copyright (C) 2020 Universitas Negeri Medan. Artikel Open Access dibawah lisensi CC-BY-4.0 (https://creativecommons.org/licenses/by/4.0)

\section{How to Cite}

Mbau, Y. W., Meha, A. M., \& Foeh, Y. (2020). Pengaruh Model Pembelajaran Kooperatif Tipe Make A Match Terhadap Hasil Belajar Siswa. Jurnal Pendidikan Biologi, 9(2), 22-27.

\section{PENDAHULUAN}

Menurut Naimnule, et al. (2016) Proses pembelajaran adalah kegiatan dan tindakan yang perlu yang dilakukan oleh siswa untuk memperoleh hasil yang lebih baik. Kesempatan untuk melakukan kegiatan dan memperoleh hasil belajar ditentukan oleh pendekatan yang digunakan oleh guru dan siswa dalam proses pembelajaran tersebut. Dalam proses pembela- jaran, guru dan siswa merupakan dua komponen yang tidak bisa dipisahkan terjalin interaksi yang aktif dapat didukung dengan penggunaan model pembelajaran. Model pembelajaran adalah strategi yang digunakan guru untuk meningkatkan motivasi belajar, sikap belajar dikalangan siswa, mampu berpikir kritis, memilliki keterampilan sosial, dan pencapaian hasil pembelajaran yang lebih Pemilihan model pembelajaran oleh guru harus 
kreatif agar mampu membuat siswa lebih aktif (Sundari, 2015).

Menurut Suparta, et al. (2015) Model pembelajaran kooperatif tipe Make $A$ Match adalah model pembelajaran yang mengharuskan untuk bekerja dalam suatu tim untuk menyelesaikan masalah, menyelesaikan tugas, atau mengerjakan suatu untuk tujuan bersama, karakteristik dari model ini adalah adanya permainan mencari pasangan menggunakan kartu yang soal dan jawaban soal dari kartu lain. Siswa mencoba menemukan jawaban dari soal dalam kartu yang dipegang siswa lain. Melalui model pembelajaran ini diharapkan siswa dapat aktif bekerja sama dalam kelompok sehingga dapat meningkatkan aktivitas dan hasil belajar siswa. Hasil belajar kognitif melihat belajar sebagai suatu yang aktif mereka berinisiatif mencari informasi untuk menyelesaikan masalah, mencari cara untuk belajar dan meng organisasi apa yang telah mereka ketahui untuk mencapai pembelajaran baru. Dalam penelitian ini untuk mengukur hasil belajar kogniti siswa diambil dari teori anderson dan Krathwohl (Shofiya, 2018).

Peneliti melakukan observasi awal pelaksanaan pembelajaran di SMP Negeri 20 Kota Kupang pada kelas VII menunjukkan bahwa penggunaan model pembelajaran yang kurang bervariasi sehingga proses belajar mengajar masih kurang maksimal dan menyebabkan hasil belajar siswa tidak mencapai kriteria ketuntasan minimal (KKM), sebagai akibat dari beberapa masalah seperti siswa kurang memperhatikan guru saat menjelaskan materi, kebanyakan siswa pasif, saat guru meminta siswa untuk mengajukan pertanyaan mengenai materi pembelajaraan tidak ada siswa yang bertanya. Kemampuan siswa dalam mengingat kembali materi pembelajaran juga masih sangat minim, saat guru memberikan pertanyaan hanya beberapa siswa saja yang aktif untuk menjawab. Hal ini disebabkan dalam pembelajaran guru monoton pada penggunaan media buku cetak sehingga menimbulkan kebosanan siswa dalam mengikuti pelajaran. Siswa juga belum maksimal dalam memahami materi yang disampaikan oleh guru, terlihat pada saat siswa sangat lambat dalam menyelesaikan mengerjakan LKS, padahal jawaban dari LKS sudah ada didalam buku belajar yang disediakan, hal ini menunjukan kemampuan analisis siswa juga sangat rendah.

Berdasarkan latar belakang masalah, maka penelitian bertujuan untuk mengetahui pengaruh model pembelajaran kooperatif tipe make a match terhadap hasil belajar siswa di SMP Negeri 20 Kupang tahun ajaran 2019/2020. Penelitian ini diharapkan dapat bermanfaat dalam memperkaya ilmu pengetahuan terkait model pembelajaran yang tepat dalam memperbaiki dan meningkatkan hasil belajar siswa. Juga memperluas wawasan dan pengetahuan guru dalam menggunakan model-model pembelajaran khususnya model pembelajaran kooperatif tipe Make A Match.

\section{METODE}

Penelitian dilakukan di Sekolah Menengah Pertama (SMP) Negeri 20 Kota Kupang. Metode penelitian adalah QuasiExperimental dengan desain posttest Only Control Group Design. Yaitu terdiri dari kelas $\mathrm{VII}^{\mathrm{H}}$ sebagai kelas eksperimen (kooperatif tipe Make $A$ Match) dengan jumlah siswa 27 siswa dan kelas VII ${ }^{\mathrm{D}}$ sebagai kelas kontrol (konvensional) dengan jumlah siswa 27 siswa. Teknik pengumpulan data menggunakan tes hasil belajar dengan instrumen tes pilihan ganda berjumlah 5 butir soal dan essay berjumlah 5 butir soal. Instrument tes berisi soal yang terdiri ranah kognitif mengingat (C1), ranah kognitif memahami (C2), dan ranah kognitif menerapkan (C3) yang diberikan kepada siswa diakhir pembelajaran atau setelah perlakuan diberikan. 
Teknik analisis data menggunakan uji-t berbantuan program SPSS 23 for windows. sebelum dilakukan uji hipotesis terlebih dahulu dilakukan uji prasyarat melalui uji normalitas dengan taraf signifikan $\alpha=0,05$ dan uji homogenitas taraf signifikan $\alpha=0,05$. suatu distribusi data dikatakan normal dan homogeny jika taraf signifikan lebih besar dari $\alpha=0,05$. Selanjutnya pengujian hipotesis dengan ketentuan jika nilai signifikan $<0,05$ maka terdapat pengaruh perlakuan kooperatif tipe Make $A$ Match dalam pembelajaran terhadap hasil belajar siswa.

\section{HASIL DAN PEMBAHASAN}

Uji prasyarat dilakukan sebelum melakukan uji hipotesi, dengan menggunakan uji homogenitas dan normalitas. Berdasarkan uji homogenitas menunjukkan nilai signifikan sebesar 0,252 lebih besar dari 0,05. artinya bahwa data penelitian homogen. Selanjutnya berdasarkan uji normalitas menunjukkan nilai Asymp. Sig. (2-tailed) sebesar 0.349 lebih besar dari nilai alfa 0,05 . Artinya data berdistribusi normal. selanjutnya dilakukan pengujian hipotesis bertujuan untuk melihat ada tidaknya pengaruh penggunaan model pembelajaran kooperatif tipe make a match terhadap hasil belajar siswa.

Hasil perhitungan uji perbedaan rata-rata yang dapat dilihat pada kolom t-test for Equality of Means. Pada Equal variances assumed diperoleh nilai t sebesar 8,19 dan taraf signifikan $\mathrm{p}=0,000$ atau kurang dari 0,05 . Artinya bahwa penggunaan model pembelajaran kooperatif tipe make a match berpengaruh secara siginfikan terhadap Hasil Belajar Siswa.

Perbedaan pada aspek-aspek hasil belajar juga terlihat antara kelas eksperimen yang menggunakan model make a macth dan kelas kontrol yang menggunakan metode konvensional (Gambar 1).

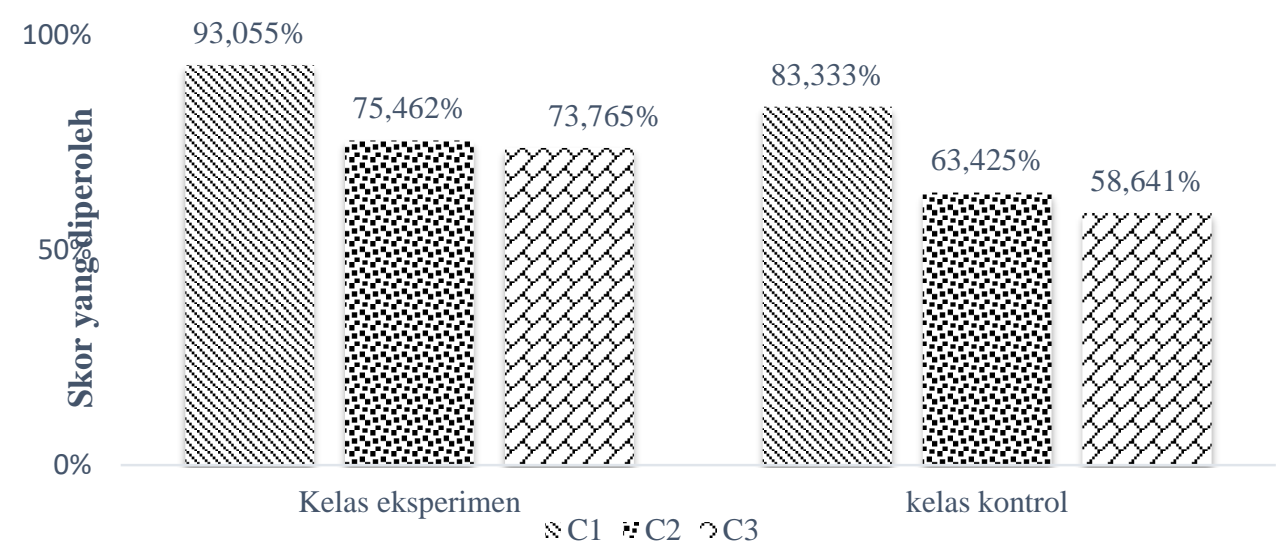

Gambar 1. Hasil Belajar Kognitif Siswa

Ranah kognitif mengingat (C1) pada kelas kontrol yang menggunakan metode konvensional mendapatkan persentase $83,333 \%$, tidak jauh berbeda dengan persentase $\mathrm{C} 1$ pada kelas eksperiemen yang menggunakan model pembelajaran kooperatif tipe make a match yaitu sebesar 93,055\%. Data tersebut menunjukkan bahwa penggunaan model atau metode pembelajaran yang berbeda tidak berdampak langsung pada kemampuan siswa dalam hal mengingat (C1). Dikarenakan ranah kognitif C1 merupakan tingkat pengetahuan yang 
paling dasar, dalam pembelajaran tampak bahwa siswa lebih mudah mengingat apa yang dilihatnya berhubungan dengan materi sistem pencernaan.

Ranah kognitif memahami (C2) pada kelas kontrol mendapatkan persentase sebesar $63,425 \%$, sedangkan ranah kognitif C2 (memahami) pada kelas eksperimen lebih baik yaitu mendapatkan persentase $75,462 \%$ artinya bahwa sudah mencapai kriteri ketuntasan minimal (KKM). Pada ranah kognitif $\mathrm{C} 2$ memiliki tingkat pengetahuan yang lebih sulit, dimana siswa lebih mudah mengingat apa yang dilihat dibandingkan memahami apa yang dijelaskan oleh guru, seperti siswa kurang memahami konsep penyebab kadar glukosa dalam darah menurun.

Ranah kognitif menerapkan (C3) pada kelas kontrol mendapatkan skor presentase $58,641 \%$ hal ini disebabkan oleh pelaksanan pembelajaran yang cendrung dikuasai guru dimana yang lebih dominan adalah metode ceramah, hal ini berbeda pada kelas eksperimen kemampuan siswa dalam aspek menerapkan (C3) sudah cukup baik dimana mendapatkan persentase $73,765 \%$, dalam pembelajaran menggunakan model kooperatif tipe make a macth siswa dilibakan secara aktif dalam pembelajaran, siswa dituntut untuk berkerja sama dengan temannya. Terbukti bahwa siswa lebih mudah menerapkan atau lebih mudah menggambarkan proses pencernaan dalam tubuh.

Rendahnya hasil belajar siswa pada kelas kontrol disebabkan dalam pembelajaran dominan menggunakan metode ceramah, sehingga initeraksi yang terjadi searah yaitu dari guru ke siswa, hal ini menyebabkan siswa kurang aktif dan kurang terlibat dalam pembelajaran seperti siswa merasa takut ketika akan bertanya, siswa sibuk dengan aktivitasnya sendiri dan tidak memperhatikan apa yang diajarkan, hal ini terjadi karena minimnya interaksi siswa dengan guru. Prastowo (2015) menjelaskan bahwa kegiatan pembelajaran model konvensional guru sebagai sumber tunggal penyajian isi pelajaran dan siswa mengikuti ceramah dari guru, mencatat, dan mengerjakan tugas dari guru Sehingga pembelejaran belum mampu meningkatkan hasil belajar siswa.

Sedangkan pembelajaran yang berlangsung pada kelas eksperimen yang menggunakan model pembelajaran kooperatif tipe Make A Match menunjukkan hasil belajar yang sangat baik. Hal ini dikarenakan model pembelajaran kooperatif tipe Make A Match merupakan model pembelajaran yang menuntut siswa memahami suatu konsep secara aktif dan menyenangkan bagi siswa sehingga siswa mudah memahami konsep tersebut dengan baik. Hal ini sesuai dengan hasil penelitian dari beberapa penelitian tentang penerapan model pembelajaran Make $\mathrm{A}$ Match yang menunjukan bahwa dapat meningkatkan motivasi dan hasil belajar siswa. (Febriana, 2011; Aliputri, 2018; \& Huss, 2006). selain itu, hal ini juga sesuai dengan pendapat dari Mulyantiningsih (2013) menjelaskan bahwa model kooperatif tipe Make A Match adalah model pembelajaran kelompok yang memiliki dua orang anggota, masing-masing anggota kelompok tidak diketahui sebelumnya tetapi dicari berdasarkan kesamaan pasangan misalnya pasangan soal dan jawaban.

Model pembelajaran kooperatif tipe Make $A$ Match membuat siswa lebih aktif dalam pembelajaran. Hal ini dikarenakan dalam penggunaan model pembelajaran kooperatif tipe Make A Match ini siswa dilatih untuk dapat menguasai materi dengan cepat, berkomunikasi dan bekerjasama dengan baik, misalnya ketika setiap siswa mendapat kartu soal dan kartu jawaban yang telah diberikan guru, siswa akan dapat mengingat materi yang ada dalam kartu, sehingga ketika berdiskusi dengan teman lainnya dapat mempermudah dan mempercepat dalam mencari pasangan atas soal atau 
jawaban dari kartu yang dimiliki. Siswa juga lebih antusias dan lebih aktif serta senang ketika melakukan proses pembelajaran di kelas, pada saat proses pembelajaran berlangsung masing-masing siswa mengungkapkan ide serta pendapat yang mereka pahami. Selain itu juga siswa mampu bekerja sama dalam kelompok, mampu menyampaikan pendapat mereka pada saat melakukan presentasi kelompok di depan kelas dengan baik yang bisa dimengerti oleh siswa lain. Miftahul (2014) menyatakan bahwa pembelajaran kooperatif tipe Make A Match dapat meningkatkan aktivitas belajar siswa baik secara kognitif maupun psikomotor serta didukung dengan penelitian yang relevan yang dilakukan Rahmawati (2015) menyatakan pembelajaran kooperatif tipe Make $A$ Match dapat menjadi salah satu alternatif pembelajaran untuk meningkatkan keaktifan siswa.

Dengan adanya kegiatan diskusi, siswa menjadi lebih aktif. Keaktifannya bertambah ketika siswa dituntut untuk mempersentasikan hasil diskusinya di depan kelas. Selain itu juga kegiatan pembelajaran memicu minat belajar siswa yang dapat menghilangkan rasa bosan siswa dikarenakan semua siswa diberikan banyak kesempatan untuk berpikir mengenai materi yang dipelajari. Hal ini dilihat pada saat siswa menampilkan kemampuan individunya untuk mengerjakan lembar kerja siswa (LKS), menjawab pertanyaan LKS dengan baik hal ini memudahkan siswa untuk tidak sekedar ingin tahu tetapi juga mampu untuk mengingat, memahami atau mengerti serta mampu menerapkan terkait materi yang dipelajari. Nadliyah, et al. (2019) mejelaskan kelebihan model pembelajaran kooperatif tipe Make $A$ Match dapat meningkatkan aktivitas belajar siswa, menyenangkan karena ada unsur permainan, selain itu juga dapat meningkatkan pemahaman dan motivasi belajar siswa, efektif sebagai sarana melati keberanian siswa untuk tampil presentasi, efektif melatih kedisiplinan siswa menghargai waktu untuk belajar.

\section{KESIMPULAN}

Penggunaan model pembelajaran kooperatif tipe Make $A$ Match memiliki pengaruh signifikan terhadap hasil belajar siswa di SMP Negeri 20 Kota Kupang Tahun Ajaran 2019/2020. Nilai signifikan pada Levene's Test for Equality of Variances adalah 0,252 yang berarti >0,05 dan pada nilai Equal variances assumed mempunyai taraf signifikan Sig. $(2$-tailed $)=0.000$ yang artinya $<0,05$.

\section{DAFTAR PUSTAKA}

Rahmawati, E. (2015). Penerapan Model Pembelajaran Make a Match Untuk Meningkatkan Keaktifan Dan Prestasi Belajar Siswa Pada Mata Pelajaran Sosiologi Kelas XI Iis 2 Di SMA Negeri 2 Surakarta Pada Tahun Pelajaran 2014/2015. Sosialitas: Jurnal Ilmiah Pendidikan Sosiologi-Antropologi, 13743.

Febriana, A. (2011). Penerapan Model Pembelajaran Kooperatif Tipe Make A Match Untuk Meningkatkan Kualitas Pembelajaran Ips Siswa Kelas V Sdn Kalibanteng Kidul 01 Kota Semarang (Application of Cooperative Learning Model Type Make A Match to Enhance Quality of Learning Social. Jurnal Kreatif: Jurnal Kependidikan Dasar, 1(2).

Miftahul, H. (2014). Model-model Pengajaran dan pembelajaran. Yogyakarta: Pustaka Pelajar.

Huss, J. A. (2006). Gifted education and cooperative learning: A miss or a match?. Gifted child today, 29(4), 19-23.

Nadliyah, A., Taufiq, M., Hidayat, M. T., \& Kasiyun, S. (2019). Pengaruh Model Pembelajaran Kooperatif Tipe Make A Match Terhadap Hasil Belajar Siswa pada Mata Pelajaran IPA. Natural Science Education Research, 2(1), 33-39.

Naimnule, L., Oetpah, V., \& Sila, V. U. R. (2016). Peningkatan Aktivitas Dan Hasil Belajar Kognitif Siswa Melalui Penerapan Model Pembelajaran Think Talk Write (Ttw) Di Smuk. Jurnal Pendidikan: Teori, Penelitian, dan Pengembangan, 1(10), 2050-2053.

Aliputri, D. H. (2018). Penerapan Model Pembelajaran Kooperatif Tipe Make A Match Berbantuan Kartu Bergambar Untuk Meningkatkan Hasil Belajar Siswa. Jurnal Bidang Pendidikan Dasar, 2(1A), 70-77. 
Mbau, et al. / Jurnal Pendidikan Biologi 9 (2) (2020) 22 - 27

Prastowo, A. (2015). Panduan Kreatif Membuat Bahan Ajar Inovatif. Yogyakarta: Diva Press.

Shofiya, K. (2018). Pengembangan Tujuan Pembelajaran PAI Aspek Kognitif Dalam Teori Anderson, L. W. dan Krathwohl, D.R. Jurnal Al Ghazali. 1(2)

Sugiyono. (2012). Metode penelitian Kuantitatif Kualitatif dan $R \& D$. Bandung: Alfabeta.
Sundari, H. (2015). Model-model pembelajaran dan pemerolehan bahasa kedua/asing. Jurnal Pujangga, 1(2), 106-117.

Suparta, D. G., Lasmawan, M. P. P. I. W., \& Marhaeni, M. P. A. N. (2015). Pengaruh model pembelajaran kooperatif teknik make a match terhadap motivasi belajar dan hasil belajar IPS. e- Journal Program Pascasarjana Universitas Pendidikan Ganesha, 5:1-12 